\title{
KAMPANYE SOSIAL ISTANA BELAJAR ANAK BANTEN DALAM PEMBANGUNAN PENDIDIKAN DI ERA DIGITAL
}

\section{Banten Children's Learning Palace Social Campaign in Development of Education in the Digital Era}

\author{
Tri Susanto ${ }^{1}$, Leonard Dharmawan, La Dono ${ }^{3}$, Irvan Roberto ${ }^{4}$ \\ ${ }^{1}$ Program Studi Ilmu Komunikasi Universitas Singaperbangsa Karawang \\ ${ }^{2}$ Sekolah Vokasi IPB \\ ${ }^{3}$ Program Studi Ilmu Komunikasi Universitas Nusa Putra Sukabumi \\ ${ }^{4}$ Program Doktoral Komunikasi Pembangunan IPB \\ E-mail: tri.susanto@staff.unsika.ac.id
}

\begin{abstract}
Social campaigns are carried out to increase public awareness and behavior of various issues faced by a country. The development of the digital era now demands that campaigns be enjoyed and seen through online media. One of the social campaign activities was the Banten Children's Learning Palace (ISBANBAN), which involved young Bantenese in contributing to education in the area by using new media. This study aims to find out and describe the ISBANBAN social campaign communication strategy with the social marketing communication approach. This research is a qualitative research with a case study strategy that takes campaign activities through new media. The main data obtained through in-depth interviews and observations. The research findings provide an overview of the social marketing communication strategy carried out by ISBANBAN that connects offline interactions, namely teaching activities in remote Banten with online interaction, namely social media as the main channel in social marketing that aims to build brand awareness for donations, through new media information that gives more broad so it is expected to reach further adopter target targets. Target adopters of multiplayer donations that not only contribute funds but also energy and thought in an effort to advance education in remote Banten.
\end{abstract}

Keywords: campaign, ISBANBAN, education development

\begin{abstract}
ABSTRAK
Kampanye sosial dilakukan untuk meningkatkan kesadaran dan perilaku masyarakat dari bermacam-macam isu yang dihadapi oleh sebuah negara. Perkembangan era digital saat ini menuntut kampanye dapat di nikmati dan di lihat melalui media online. Salah satu Kegiatan kampanye sosial yang dilakukan yaitu Istana Belajar Anak Banten (ISBANBAN) yaitu melibatkan anak muda Banten dalam berkontribusi dalam pendidikan di daerah dengan menggunakan new media. Penelitian ini bertujuan untuk mengetahui dan mendeskripsikan strategi komunikasi kampanye sosial ISBANBAN dengan pendekatan komunikasi pemasaran sosial. Penelitian ini merupakan penelitian kualitatif dengan strategi studi kasus yang mengambil aktivitas kampanye melalui new media. Data utama diperoleh melalui wawancara mendalam dan observasi. Temuan penelitian memberikan gambaran Strategi Komunikasi pemasaran sosial yang dilakukan oleh ISBANBAN yang menghubungkan interaksi offline yaitu kegiatan mengajar di pelosok Banten dengan interaksi online yaitu media sosial sebagai saluran utama dalam pemasaran sosial yang bertujuan membangun brand awareness terhadap donasi kegiatan, melalui new media informasi yang berikan lebih luas sehingga diharapkan menjangkau sasaran target adopter yang lebih jauh. Target adopter donasi multiplayer yang tidak hanya menyumbangkan dana namun juga tenaga dan pemikiran dalam usaha memajukan pendidikan di pelosok Banten.
\end{abstract}

Kata kunci: kampanye, ISBANBAN, pembangunan pendidikan 


\section{PENDAHULUAN}

Komunikasi pemasaran sosial merupakan salah satu pendekatan yang menanggulangi masalah sosial. Konsep komunikasi pemasaran sosial digunakan untuk menangani perma-salahan sosial terhadap penyebaran ide dan gagasan baru dalam upaya peningkatan kesajahteraan masyarakat khususnya pendidikan. Dilihat dari hal tersebut maka pemasaran sosial memang digunakan dalam penyebaran ide atau gagasan baru. Dalam social marketing (pemasaran sosial) yang dimaksud dengan produk adalah sesuatu yang ditawarkan untuk dibeli, yang berbentuk perilaku yang diharapkan dan manfaat perilaku tersebut. Hal yang ditawarkan tersebut bisa termasuk juga sebuah barang dan layanan untuk mendukung perubahan perilaku dari sasaran. Dalam pemasaran komersial hal tersebut sering dikatakan sebagai paket manfaat yang ditawarkan pada pasar untuk memenuhi kebutuhan pasar.

Salah satu kegiatan pemasaran sosial adalah kampanye sosial yang banyak dilakukan oleh masyarakat untuk meningkatkan kesadaran dan perilaku. Perilaku itu cenderung sejalan dengan norma dan nilai yang ada. Kampanye seringkali menyangkut soal pengarahan, pemerkuatan dan penggerakan kecenderungan yang ada kearah tujuan yang diperkenankan secara sosial seperti pemungutan suara, pembelian barang-barang, pengumpulan dana peningkatan kesehatan dan keselamatan dan sebagainya. Perkembangan teknologi memudahkan aktivitas kampanye. Jika dahulu kampanye hanya dilakukan di tempat ramai dengan menggunakan sound system dihadapan publik, kini hal seperti itu masih kurang menjangkau khalayak yang tidak berada ditempat kampanye. Dengan adanya internet, kampanye dapat dilakukan secara online di dunia maya melalui, email, chating, web pages, blog, video dan sebagainya. Penggunaan internet sebagai media komunikasi dalam kegiatan kampanye menuntut pengetahuan dan kreatifitas tinggi. Kampanye yang memiliki nilai kretifitas yang tinggi akan menarik banyak khalayak untuk ikut bergabung sebagai bentuk dukungan dalam menyukseskan sebuah proyek yang sedang di kampanyekan.

Salah gerakan sosial yang sering melakukan kampanye pembangunan pendidikan di pelosok daerah Provinsi Banten Adalah Istana Belajar Anak Banten. ISBANBAN adalah Foundation is a youth-led non profit social foundation established on February, 10th 2013. The single goal in sight is to helping children in underprivilleged families in rural area of Banten to attain access an excellence of education. Adapun dalam pelaksanaan Gerakan sosial ini membutuhkan dukungan mulai dari dana, Sumber daya manusia serta pemikiran. Untuk itu ISBANBAN melakukan pemasaran social agar gerakan ini terus berkelanjutan. Berdasarkan lata belakang ini, maka 1) Bagaimana proses pemasaran sosial yang dilakukan oleh ISBANBAN dalam Pembangunan Pendidikan di Pelosok Provinsi Banten ? 2) Apakah Pemasaran Sosial ISBANBAN efektif dilakukan?

\section{TINJAUAN PUSTAKA}

Rogers dan Storey (dalam Venus 7: 2004) mengungkapkan kampanye sebagai serangkaian tindakan komunikasi yang terencana dengan tujuan menciptakan efek tertentu pada sejumlah besar khalayak yang dilakukan secara berlanjutan pada kurun waktu tertentu. Pada definisi ini, maka setiap aktivitas kampanye komunikasi setidaknya harus mengandung empat hal yakni: (1) tindakan kampanye yang ditujukan untuk menciptakan efek atau dampak tertentu 
(2) jumlah khalayak sasaran yang besar, (3) biasanya dipusatkan dalam kurun waktu tertentu, dan (4) melalui serangkaian tindakan komunikasi yang terorganisasi.

\section{METODE PENELITIAN}

Jenis penelitian yang digunakan adalah penelitian studi kasus (case study). Menurut K. Yin (2012:1) secara umum penelitian studi kasus mengacu pada bentuk-bentuk pertanyaan how (bagaimana) atau why (mengapa). Menurut pendapat K. Yin studi kasus adalah suatu inkuiri empiris yang:

-Menyelidiki fenomena di dalam konteks kehidupan nyata, bilamana

-Batas-batas antara fenomena dan konteks tak tampak dan tegas; dan dimana:

-Multisumber bukti dimanfaatkan.

Pelaksanaan penelitian kurang lebih berlangsung selama tiga bulan, dimana dalam teknik pengumpulan data yang digunakan secara langsung peneliti akan melakukan indepth interview, observasi dan pengumpulan dokumen relevan terhadap penelitian. Untuk sampling yang digunakan, peneliti menggunakan purposive samp-ling guna memperoleh kedalaman atas data yang diperoleh. Sifat sampling berkembang sesuai kebutuhan, dimana informan di pilih berdasarkan pertimbangan atas dasar ketercukupan informasi yang dimilikinya. Dalam penelitian ini penulis menggunakan teknik analisis data milik Miles dan Huberman. Terdapat tiga jalur analisis data kualitatif yaitu reduksi data, penyajian data, dan penarikan kesimpulan (Miles dan Huberman, 1992:20).

\section{HASIL DAN PEMBAHASAN}

ISBANBAN merupakan gerakan sosial yang mengajak anak muda untuk berkontribusi membangun pendidikan. Adapun visi dan misinya adalah sebagai berikut:

\section{VISI}

Every Children in Rural Area of Banten attain Access an Excellence of Education MISI

Inspire youth make a movement who contribute to ensure that children growing up in underprivileged families get lifelong learning opportunities to access an excellence of education

\section{VALUES}

CARE VALUE: CARE \& SHARE Berbagai hal yang kami jalankan dalam organisasi berlandaskan kepada kepedulian dan kemauan untuk berbagi kepada sesama.

WORK VALUE: IMPACT \& SUSTAINABLEPerwujudan cara kerja yang kami lakukan di ISBANBAN Foundation dengan tujuan untuk memberikan hasil kinerja yang berdampak dan berkelanjutan.

VOLUNTEERISM VALUE: RESPECT Singkatan (R) Reminder , (E) Emphaty, (S) Special, (P) Powerful , (E) Engage , (C) Collaboration, (T) Trust. Nilai-nilai RESPECT ini yang kami jaga untuk menjaga semangat dan keterlibatan relawan di ISBANBAN Foundation.

\section{GOALS}

Berdasarkan adanya berbagai masalah pendidikan di Banten, ISBANBAN Foundation menetapkan sikapnya untuk menjadi pelopor perubahan dalam menciptakan solusi. ISBANBAN Foundation dalam menciptakan sebuah solusi maka dibutuhkan sebuah tujuan. Kami berfokus salah satunya pada tujuan 
pembangunan dunia (Sustainble Development Goals 2030 Poin 4 Pendidikan) dengan mempertimbangkan local problem ada. Maka terbentuklah 3 tujuan utama gerakan ISBANBAN Foundation, yaitu:

1. Meningkatkan Akses Pendidikan anak di Pelosok Desa Banten.

2. Meningkatkan Literasi Minat Baca Anak di Pelosok Desa Banten.

3. Meningkatkan Angka Partisipasi Sekolah Anak di Sekolah di Pelosok Desa Banten.

Dalam kegiatan kampanye ISBANBAN terdapat kegiatan komunikasi sosial marketing merupakan instrumen pendekatan baru dalam menanggulangi masalah sosial. Konsep komunikasi sosial marketing digunakan untuk menangani permasalahan sosial terhadap penyebaran ide atau gagasan baru dalam upaya peningkatan kesejahteraan masyarakat. Dilihat dari hal tersebut maka sosial marketing memang digunakan penyebaran ide atau gagasan baru Kampanye ISBANBAN ini,dimana dalam penyebaran ide dalam social marketing menggunakan metode kampanye perubahan sosial (Social change campaigns).

Kotler dan Roberto (1989:24) menyatakan pemasaran sosial adalah strategi untuk mengubah perilaku yang mengkombinasikan elemen-elemen terbaik pendekatan tradisonal dan perubahan sosial dalam sebuah kerangka karya perencanaan dan pelaksanaan teringresai serta memanfaatkan kemajuan teknologi komunikasi dan keterampilan pemasaran.

Tahapan yang perlu dilakukan dalam memasarkan sebuah ide atau produk sosial adalah :

\section{Analizing the social marketing environment}

Hasil analisis lingkungan menggambarkan bahwa masih banyak masyarakat yang memiliki pemahaman bahwa pendidikan adalah hanya tanggung jawab pemerintah. Sehingga ISBANBAN mengajak masyarakat dalam usaha memajukan pendidikan di pelosok desa dengan bergabung menjadi Volounteer serta donatur.

2. Researching and selecting the target adopter population

Hasil penelitian masyarakat Indonesia masih banyak yang peduli denga pendidikan dipelosok desa yang menjadi target adopter dinilai.

3. Designing social marketing objetives and strategies

Sasaran serta strategi komunikasi pemasaran sosial dilakukan dengan cara menghubungkan kegiatan yang dilakukan ISBANBAN di pelosok daerah Provinsi Banten dan mengunggah kegiatan tersebut melalui media sosial.

4. Planning social marketing mix programs

Adapun mix program yang digunakan dalam tahap pemasaran sosial menggunakan Kampanye Sosial yang mengajak masyarakat untuk bergabung dalam gerakan ISBANBAN dengan menggunakan pesan-pesan pendidikan.

5. Organizing, Implementing, controlling, and evaluating the social marketing effort

Mengorganisir sumber daya pemasaran, melaksanakan program bauran pemasaran sosial, mengawasi atau mengontrol kinerja dari program-program, dan mengevaluasi hasil dari pelaksanaan program. 
Analisis terdahulu mengenai faktor kesuksesan serta kemungkinan kegagalan kampanye perubahan sosial digunakan untuk menspesifikan elemen yang ada. Elemen tersebut antara lain :

1. Cause (permasalahan) adalah penyebaran informasi meng-enai kampanye pendidikan adalah tanggung jawab bersama melalui ISBANBAN masyarakat diajak untuk ambil bagian dalam pendidikan di pelosok Indonesia Khususnya Provinsi Banten.

2. Change Agent ( Agen Perubahan) dalam kegiatan kampanye ini yang berperan sebagai agen perubahan adalah ISBANBAN Founder Panji Aziz Pratama, pria asal desa Kukun, Cikande, Serang.

3. Channels (Media atau saluran) media yang digunakan dalam kampanye ISBANBAN adalah media sosial seperti facebook, twitter,website,instgram dll

4. Strategy change (strategi Pengubah ) mengajak masyarakat bergabung dalam tiga program yang ditawarkan, yaitu:

a. BUILD berfokus pada pendirian taman baca sebagai upaya peningkatan budaya minat baca untuk anak anak di pelosok desa Banten. Hal pertama yang ISBANBAN Foundation lakukan dalam membantu pendidikan anak di desa adalah dengan membangun sebuah taman baca sebagai pusat belajar dan membaca bagi anak-anak di desa. Dengan berdirinya sebuah taman baca, anak-anak dapat berkumpul untuk bersama mencari wawasan baru dari buku bacaan. Taman baca juga digunakan untuk kegiatan belajar-mengajar setiap hari minggu yang dilakukan relawan kepada anak- anak di desa. Sejak 10 Februari 2013 dinyatakan sebagai hari lahir ISBANBAN Foundation dengan didirikannya taman baca pertama ISBANBAN di Kp. Sukamaju, Desa Citasuk, Kecamatan Padarincang Kabupaten Serang, Banten. Sampai saat ini ISBANBAN Foundation telah memiliki 14 taman baca yang tersebar di 7 kabupaten/kota se- Banten dan lebih dari 2000 koleksi buku di 14 taman baca yang kami dirikan.

Mendirikan sebuah taman baca diperlukan sebuah gerakan donasi buku yang kami namakan 'Gerakan Berbagi Buku', sebuah program penggalangan donasi buku dalam rangka meningkatkan budaya minat baca anak anak desa dan mendorong wawasan anak yang lebih luas.

b. TEACH berfokus pada pengajaran setiap hari minggu yang dilakukan oleh relawan muda usia 18 - 25 tahun kepada anak anak di desa binaan ISBANBAN Foundation. Program ini dinamakan Minggu Belajar. 3 Konten utama minggu belajar mengarah kepada :

1. Wawasan dan Pendampingan Pencapaian Mimpi Anak

2. Kreatifitas dan Pengembangan Potensi Diri Anak

3. Peningkatan Kemampuan Akademik Anak

Program Minggu Belajar telah dilaksanakan sejak ISBANBAN Foundation berdiri pada tahun 2013. Selama 5 tahun program berjalan, telah turut serta 642 relawan muda yang pernah turun ke desa untuk mengajar 455 anak -anak di 14 titik desa binaan ISBANBAN Foundation. Program Minggu belajar dirancang untuk mencapai terciptanya akses terhadap informasi, keterampilan dan wawasan anak anak di pelosok desa Banten.

c. SUPPORT berfokus pada pemberian beasiswa bagi anak anak yang lemah dalam ekonomi namun memiliki potensi diri untuk dikembangkan. Program ini dinamakan ISBANBAN Dream Scholarship atau disebut I DREAMS. 
Beasiswa diberikan dalam bentuk dana bantuan biaya sekolah, pembelian seragam dan peralatan sekolah, serta pembiayaan buku pelajaran sekolah. harapannya anak penerima beasiswa yang kami sebut I DREAMS scholars dapat terbantu berbagai kebutuhan sekolahnya dan harapan besarnya dapat melanjutkan sekolah ke tingkatan yang lebih tinggi. Selain pemberian dana beasiswa, akan diberikan juga mentoring khusus persiapan lanjut sekolah yang meliputi kemampuan komunikasi, bersosialisasi sampai pada pelatihan penguasaan teknologi dan kewirausahaan. I DREAMS adalah upaya ISBANBAN Foundation untuk meningkatkan angka partisipasi sekolah dan menurunkan tingkat putus sekolah di Banten. Tahun 2018 terdapat 10 anak akan dibeasiswakan hingga di jenjang Sekolah Menengah Pertama sampai 3 tahun.

\section{Strategi Komunikasi Kampanye}

Dalam kampanye ISBANBAN melalui media online yaitu sebagai promosi sebagai Brand Awareness gerakan sosial yang mengajak masyarakat karena ISBANBAN ingin menjadikan donasi dari masyarakat sebagai pilar penopang penting bagi pendanaan gerakan sosial ini.

Pengembangan pendanaan dalam gerakan ISBANBAN berupa donasi bermaksud untuk mengajak masyarakat bersama-sama bergotong royong dalam meningkatkan kualitas pendidikan di Pelosok daerah Indonesia Khususnya di Provinsi Banten.

Proses komunikasi dalam kampanye pada hakikatnya adalah proses penyampaian oleh seseorang (komunikator) kepada orang lain (komunikan). Melalui gambar proses komunikasi sangat terlihat bahwa suatu komunikasi merupakan suatu proses penyampaian pesan dari seorang komunikator (encoder) kepada komunikan (decoder). Sebuah proses komunikasi memuat beberapa komponen serta elemen yang mempengaruhi kelangsungan serta kelancaran proses yang berlangsung itu sendiri.

1. Komunikator

Komunikator menjadi faktor pendorong dalam mendorong masyarakat mengambil keputusan melaksanakan kampanye ISBANBAN. Peran sebagai komunikator diemban oleh PANJI Aziz Pratama, 21, memiliki jejak panjang di dunia organisasi dan gerakan sosial. Selama lebih dari tujuh tahun, ia menjelajahi berbagai kegiatan skala daerah hingga internasional. Ia pun membagi kiprahnya pada anak-anak muda di berbagai forum di di Amerika Serikat (AS), India, serta Malaysia. Ia lalu terpilih sebagai salah satu dari 21 anak muda se-Asia Tenggara yang dinobatkan sebagai Young Southeast Asian Leaders. Hadiahnya, beasiswa Leadership Training di Northern Illinois AS selama lima minggu.

2. Pesan

Isi dari pesan yang disampaikan adalah semua berkaitan dengan permasalahan pendidikan dan bagaimana cara membantu pendidikan di pelosok Indonesia. Permasalahan ini muncul karena ketimpangan kualitas pendidikan, untuk itu masyarakat diajak untuk turut turun tangan dalam pembenahan pendidikan melalui Gerakan ISBANBAN. 
3. Saluran

Saluran komunikasi yang digunakan adalah media sosial. Mulai dari Kitabisa.com, website Isbanban.org hingga media sosial yaitu Facebook, Twitter dan Instagram.

4. Komunikan

McQuail \& Windahl (dalam Venus 98:2011) Mendefiniskan khalayak sasaran sebagai sejumlah besar orang yang pengetahuan, sikap dan perilakunya akan diubah melalui kegiatan kampanye. Besarnya jumlah khalayak sasaran ini mengindikasikan bahwa mereka memiliki karakteristik yang beragam. Akibatnya cara mereka merespons pesan-pesan kampanye juga akan berbedabeda. Dalam hal ini komunikan pada kampanye ISBANBAN adalah orangorang yang peduli dengan pendidikan.

5. Efek

Efek yang baik dimana masyarakat lebih memahami gerakan ISBANBAN dan juga dapat mengambil bagian sebagai relawan. Baik relawan donatur, relawan tenaga dan juga donator dalam pemberian buku pelajaran yang dibutuhkan media sosial dalam Kampanye ISBANBAN. Dalam pelaksanaan Kampanye ISBANBAN terbagi menjadi dua bagian yaitu Offline dan Online. Kegiatan Offline adalah proses pembelajaran yang dilakukan oleh relawan di pelosok Provinsi Banten. Sedangkan online adalah kampanye yang dilakukan melalui media sosial berupa foto kegiatan yang dilakukan relawan dan yang dibutuhkan anak-anak di pelosok Provinsi Banten dengan 7 desa binaan yaitu Cilegon, Kabupaten Serang, Kabupaten Tangerang, Kota Serang, Lebak, Pandeglang, Tangerang Selatan.

Secara keseluruhan kegiatan pemasaran sosial melalui media sosial dapat di deskripsikan sesuai langkah perencanaan pemasaran sosial kampanye ISBANBAN Menurut Philip Kotler dan Nancy Lee.

1. Latar belakang, Tujuan dan Fokus

Latar Belakang : Ketimpangan pendidikan di pelosok Indonesia Khususnya Provinsi Banten sehingga memunculkan gerakan sosial di bidang pendidikan yaitu Istana Belajar Anak Banten namun masih menbutuhkan Pendanaan untuk menggerakan kegiatan Isbanba. Tujuan dan fokus : Mengajak masyarakat untuk ikut bergotong royong dalam pilar pendanaan untuk pendidikan di pelosok Indonesia Khususnya Provinsi Banten.

2. Analisis Situasi

Masih banyak masyarakat yang memiliki pemahaman bahwa pendidikan adalah tanggung jawab pemerintah. Sehingga ISBANBAN mengajak masyarakat dalam usaha memajukan pendidikan di pelosok desa Provinsi Banten dengan bergabung menjadi donatur sebagai bentuk kepedulian.

Faktor Organisasi: merupakan Gerakan Sosial bidang pendidikan yang sudah banyak mendapatkan penghargaan yang memiliki tim yang solid didukung oleh relawan yang tersebar di seluruh wilayah serta memiliki mitra pendukung yang banyak dan perusahan besar sehingga menimbulkan kepercayaan masyarakat

3. Memilih dan Menjelaskan Target audience

Target Audiens utama dalam program ini adalah semua kalangan yang peduli pendidikan di Pelosok Indonesia Khususnya Provinsi Banten. 
4. Mengatur Objek Pemasaran dan Tujuan (Perilaku, Pengetahuan, Keyakinan) Dalam kampanye ini masyarakat diajak untuk lebih peduli pendidikan. Sekecil apapun usahanya. ISBANBAN memberikan wadah untuk masyarakat dalam kemajuan pendidikan di Indonesia Melalui Donasi baik dalam bentuk dana, tenaga, buku dan bentuk lainnya.

5. Mengidentifikasi Hambatan Audiens, Manfaat, dan Pesaing. Hambatan: masih banyak masyarakat yang belum mengenal ISBANBAN. Manfaat: Sebagai ajang promosi Iuran publik yang akan meningkatkan brand awareness terhadap masyarakat.

Pesaing: ISBANBAN tidak memilik pesaing bahkan saling mendukung antar sesama gerakan sosial.

6. Membuat Positioning yang Diinginkan

Positioning yang diharapkan oleh ISBANBAN menjadi gerakan sosial tingkat Provinsi yang dapat mengajak masyarakat dalam mencerdaskan anak-anak di pelosok Indonesia khususnya Provinsi Banten dan Juga sebagai sekolah kepemimpinan bagi anak muda yang Relawan muda.

7. Mengembangkan Bauran Pemasaran Strategis (The 4P)

a. Product

Product dalam kampanye ini merupakan ide atau gagasan. Ide gagasan seperti yang diurai di atas adalah pengembangan pendanaan dalam gerakan ISBANBAN berupa donasi yang bermaksud untuk mengajak masyarakat bersama-sama bergotong royong dalam meningkatkan kualitas pendidikan di Pelosok daerah Indonesia.

b. Price

Price merupakan harga yang bisa berupa pengorbanan yang berbentuk uang, kesempatan dan waktu konsumen. Dalam kampanye ini ISBANBAN tidak hanya mengajak masyarakat untuk donasi berupa dana saja, namun juga donasi pemikiran dan donasi kehadiran. Donasi pemikiran atau ide adalah masyarakat diajak bersama-sama membantu Relawan yang bertugas dalam membuat metode pembelajaran, surat semangat dan lainnya yang dibutuhkan di daerah. Untuk iuran kehadiran adalah hadir selama satu tahun di daerah pelosok

c. Place

Place (tempat) merujuk pada cara untuk menjangkau konsumen. Selain itu tempat merupakan saluran-saluran untuk mencapai konsumenkonsumen dalam memberikan informasi.

d. Promotion

Promotion (Promosi), merujuk kepada kampanye pemasaran untuk mempromosikan keuntungan-keuntungan dari pertukaran kepada khalayak sasaran seperti penggunaan media radio, surat kabar, dan lain sebagainya. Promosi iuran publik dalam kampanye ISBANBAN merupakan sebuah kampanye yang menggunakan media sosial sebagai medianya.

8. Menentukan Rencana Evaluasi

Rencana garis besar evaluasi menjelaskan mengapa akan mengevaluasi, apa yang akan diukur, bagaimana dan kapan. Apa yang diukur sering masuk ke salah satu kategori di bawah: 
a. Input

Sumber daya yang dialokasikan untuk kampanye dan usaha program adalah relawan muda serta stake holder yang mendukung gerakan ISBANBAN.

b. Output

Kegiatan program yang dilakukan untuk mempengaruhi khalayak untuk melakukan perilaku yang diinginkan adalah kampanye ISBANBAN yaitu mengajak masyarakat untuk berlari sebagai bentuk kepedulian terhadap anak-anak di pelosok Indonesia khususnya Provinsi Banten dan juga mempromosikan gerakan donasi.

c. Outcomes

Tanggapan audiens terhadap output, yaitu kegiatan yang unik dan jarang dilakukan oleh gerakan sosial lainnya yaitu menghubungkan kota dan desa binaan agar dapat membantu anak-anak di pelosok Banten.

d. Return and Investment

Peningkatan dalam kondisi sosial. Meningkatnya kepedulian masyarakat melalui gerakan-gerakan positif yang digelar oleh ISBANBAN.

9. Membentuk Anggaran Kampanye dan Mencari Pendanaan

Mengidentifikasi daftar harga untuk strategi dan kegiatan dengan biaya yang terkait implikasi. Dalam pelaksanaan anggaran pendanaan kampanye ISBANBAN yang disampaikan oleh ISBANBAN dan merupakan hasil dari kerjasama bersama dengan relawan dan stakeholder pendukung gerakan ini.

10. Garis Besar Rencana Pelaksanaan

Rencana pelaksanaan fungsi sebagai dokumen kerja untuk berbagi dan melacak upaya yang direncanakan. Paling umum, rencana mewakili minimal kegiatan 1 tahun, dan idealnya 2 atau 3 tahun.

\begin{tabular}{|c|c|c|c|}
\hline What & Who & When & How mисh \\
\hline $\begin{array}{l}\text { Masyarakat dapat } \\
\text { bersama membantu } \\
\text { menuntaskan } \\
\text { ketimpangan } \\
\text { pendidikan melalui } \\
\text { gerakan ISBANBAN }\end{array}$ & $\begin{array}{l}\text { Masyarakat } \\
\text { Indonesia }\end{array}$ & $\begin{array}{l}\text { Selama Program } \\
\text { ISBANBAN } \\
\text { berlangsung }\end{array}$ & $\begin{array}{l}\text { Pendanaan } \\
\text { operasional } \\
\text { program } \\
\text { ISBANBAN }\end{array}$ \\
\hline
\end{tabular}

\section{KESIMPULAN DAN SARAN}

Keberadaan khalayak yang bersifat heterogen, dengan memunculkan komunitas baru yang peduli dengan pendidikan di pelosok negeri . banyaknya peserta yang ikut dalam kampanye baik itu di kota jakarta dan kota besar lainnya serta anak-anak dipelosok negeri membuat pemahaman bahwa hal kecil seperti olahraga lari dapat menyatukan Pendidikan di Indonesia. Terciptanya keinginan untuk memajukan pendidikan di pelosok negeri. Kegiatan kampanye ISBANBAN dalam promosi Donasi gerakan ISBANBAN dengan tujuan meningkatkan pemahaman masyarakat bahwa pendidikan adalah tanggung jawab bersama. Dengan iuran publik masyarakat sudah berperan penting untuk pendidikan pelosok khusunya Provinsi Banten melalui relawan yang berada di desa binaan, dengan mengikuti donasi berarti masyarakat sudah ambil bagian dalam kemajuan pendidikan. Kampanye ini juga sebagai pengenalan konsep pendanaan yang aman 
dan terbuka melalui crowdfunding yang sudah memiliki sistem yang baik, iuran publik akan menjadi penopang pilar pendanaan gerakan ISBANBAN.

Dari seluruh tahapan (kajian awal, riset/konsultasi, pengembangan pesan, pelaksanaan dan pemantauan) upaya yang dilakukan dalam kampanye ISBANBAN telah memenuhui dan menerapkan keberhasilan kampanye gerakan sosial. Sebagai pemasaran sosial ide kampanye lari bersama dengan strategi media yang dikemas menggunakan sejumlah media untuk memastikan pesan-pesan kunci akan dapat disebarkan secara luas, dikenali, dipahami dan sedapat mungkin diadaptasi oleh publik yangmenjadi target kampanye ini. Pelibatan daerah pelosok Indonesia menjadi nilai lebih dalam kampanye ini karena adanya niat bersama mendukung kampanye ISBANBAN sehingga menjadi kegiatan yang meningkatkan Brand Awareness terhadap gerakan ISBANBAN.

Aktivitas lari sebagai bentuk kampanye merupakan aktivitas yang mudah dilakukan siapa saja dan dimana saja sebagai bentuk kebersamaan antara anakanak di pelosok Indonesia khususnya Provinsi Banten dengan masyarakat dikotakota besar. Penggunaan media sosial sebagai saluran informasi sangat membantu menghubungkan antara pelosok Indonesia dengan kota-kota besar lainnya yang melakukan kegiatan kampanye. Koordinasi yang terencana, terpadu, dan terukur penting untik dibangun dengan pelaksanan kampanye di daerah dan kota lainnya. Sehingga dapat melaksanaakan kampanye yang serentak dengan tujuan yang sama. Peneliti melihat subyek penelitian ini sebagai sebuah kasus aktual komunikasi untuk gerakan sosial, terutama penggunaan media, menjadi pembelajaran yang menarik buat pengembangan sebuah upaya bagi komunikasi.

\section{DAFTAR PUSTAKA}

Arifin, Anwar. 2003. Komunikasi Poitik : Paradigma-Teori-Aplikasi-Strategi dan Komunikasi Politik Indonesia. Jakarta. PT. Balai Pustaka

Bungin, Burhan. 2010. Analisis Data Penelitian Kualitatif. Jakarta. PT Raja Grafindo Persada

Cangara, Hafied. 2009. Komunikasi Politik: Konsep, Teori, dan Strategi. Jakarta: PT. Raja Grafindo Persada

Davies, R. 2014. Civil Crowdfunding: Participatory communities. Entepreneurs and the political economy of place. Cambridge: Departement of Comparative Media Studies,Massachusetts Institute of Technology.

Effendi, Uchjana onong. 2004. Ilmu Komunikasi Teori dan Praktek .Bandung: PT Remaja Rosdakarya

JK. Sutopo. 1986. Komunikasi Pembangunan dan Komunikasi Kependudukan. Surakarta: Fakultas Ilmu Sosial dan Ilmu Politik Universitas Sebelas Maret

Kotler,Philip and Roberto, Eduardo L, 1989, Social Marketing Strategic changing public Behavior, Collier Macmillan-canada

Liliweri, Alo M. S. 1991. Memahami Peran Komunikasi Massa Dalam Masyarakat. Bandung : Citra Aditya Bakti

Mardikanto, Totok. 2010. Komunikasi Pembangunan. Surakarta : UPT Penerbitan dan percetakan UNS 
McLuhan, Marshall. 1990. Understanding Media: The Extention of Man .London: Routlege

Miles, Matthew dan Huberman, A. Michael. 1992. Analisis data Kualitatif: Buku sumber tentang metode-metode baru. Jakarta :UI Press

Morisan. 2013. Teori Komunikasi: Individu Hingga Massa. Jakarta : Kencana Prenada Media Group

Moleong, Lexy. J. 2011. Metodologi Penelitian Kualitatif. Bandung. PT. Remaja Rosdikarya

Newsom, Doug. et.al. 1993. This is PR: The Realities of Public Relations Belmint, California: Wadsworth

Nimmo, Dan. 2005. Komunikasi Politik. Bandung. PT. Remaja Rosdakarya Offset

Pfau, Michael dan Parrot, Roxanne.1993 Persuasive Communication Campaign Massachussets; Allyn dan Bacon

Pawito.2007. Penelitian Komunikasi Kualitatif. Yogyakarta: LKIS

Rogers, Everett M. 2003. Diffusion of Innovations Third Edition. New York: The Free Press

Aplikasi Jakarta: PT RajaGrafindo Persada, 2007

Stephen W, Littlejohn. 2008. Theories Of Human Communication (Ninth Edition). Belmont, CA : Wadsworth

Yin, Robert K. 2013. Studi Kasus : Desain dan Metode. Jakarta: PT. Raja Grafindo Persada.

Venus, Antar. 2007. Manajemen Kampanye: Panduan Teoritis dalam mengefektifkan Kampanye Komunikasi Bandung: PT. Simbiosa Rekatama Media

Sumaryo. 2006. Peranan Media Massa Dalam Penyebaran Informasi Pertanian Di Kalangan Petani Sayuran di Lampung.Jurnal Penyuluhan, Vol 2 (4): 1622. 